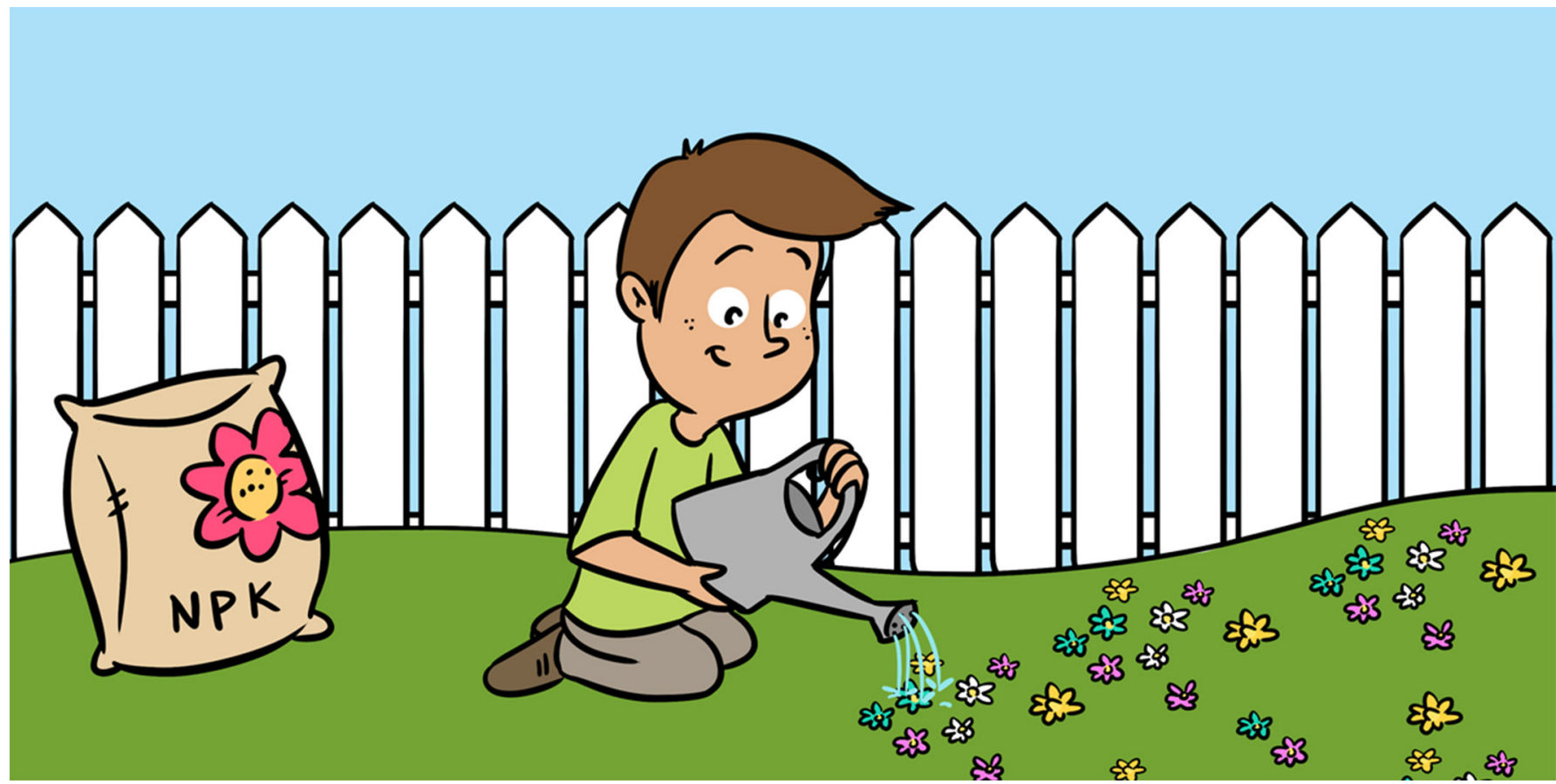

\title{
WHAT IS THE NITROGEN CYCLE AND WHY IS IT KEY
}

\section{TO LIFE?}

Miriam R. Aczel*

Centre for Environmental Policy, Imperial College London, London, United Kingdom

YOUNG REVIEWERS:

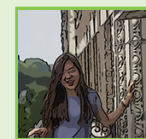

JULIETTE

AGE: 14

CLAIRE

AGE: 15
Nitrogen, the most abundant element in our atmosphere, is crucial to life. Nitrogen is found in soils and plants, in the water we drink, and in the air we breathe. It is also essential to life: a key building block of DNA, which determines our genetics, is essential to plant growth, and therefore necessary for the food we grow. But as with everything, balance is key: too little nitrogen and plants cannot thrive, leading to low crop yields; but too much nitrogen can be toxic to plants, and can also harm our environment. Plants that do not have enough nitrogen become yellowish and do not grow well and can have smaller flowers and fruits. Farmers can add nitrogen fertilizer to produce better crops, but too much can hurt plants and animals, and pollute our aquatic systems. Understanding the Nitrogen Cycle-how nitrogen moves from the atmosphere to earth, through soils and back to the atmosphere in an endless Cycle-can help us grow healthy crops and protect our environment. 


\section{INTRODUCTION}

Nitrogen, or N, using its scientific abbreviation, is a colorless, odorless element. Nitrogen is in the soil under our feet, in the water we drink, and in the air we breathe. In fact, nitrogen is the most abundant element in Earth's atmosphere: approximately $78 \%$ of the atmosphere is nitrogen! Nitrogen is important to all living things, including us. It plays a key role in plant growth: too little nitrogen and plants cannot thrive, leading to low crop yields; but too much nitrogen can be toxic to plants [1]. Nitrogen is necessary for our food supply, but excess nitrogen can harm the environment.

\section{WHY IS NITROGEN IMPORTANT?}

The delicate balance of substances that is important for maintaining life is an important area of research, and the balance of nitrogen in the environment is no exception [2]. When plants lack nitrogen, they become yellowed, with stunted growth, and produce smaller fruits and flowers. Farmers may add fertilizers containing nitrogen to their crops, to increase crop growth. Without nitrogen fertilizers, scientists estimate that we would lose up to one third of the crops we rely on for food and other types of agriculture. But we need to know how much nitrogen is necessary for plant growth, because too much can pollute waterways, hurting aquatic life.

\section{DNA}

Deoxyribonucleic acid, a self-replicating material which is present in nearly all living organisms as the main component of chromosomes, and carrier of genetic information.

RNA

Ribonucleic acid, a nucleic acid present in all living cells, acts as a messenger carrying instructions from DNA.

\section{NITROGEN IS KEY TO LIFE!}

Nitrogen is a key element in the nucleic acids DNA and RNA, which are the most important of all biological molecules and crucial for all living things. DNA carries the genetic information, which means the instructions for how to make up a life form. When plants do not get enough nitrogen, they are unable to produce amino acids (substances that contain nitrogen and hydrogen and make up many of living cells, muscles and tissue). Without amino acids, plants cannot make the special proteins that the plant cells need to grow. Without enough nitrogen, plant growth is affected negatively. With too much nitrogen, plants produce excess biomass, or organic matter, such as stalks and leaves, but not enough root structure. In extreme cases, plants with very high levels of nitrogen absorbed from soils can poison farm animals that eat them [3].

\section{WHAT IS EUTROPHICATION AND CAN IT BE PREVENTED?}

Excess nitrogen can also leach-or drain-from the soil into underground water sources, or it can enter aquatic systems as above ground runoff. This excess nitrogen can build up, leading to a process 


\section{EUTROPHICATION}

Excessive amount of nutrients (such as nitrogen) in a lake or other body of water, which causes a dense growth of aquatic plant life, such as algae.

\section{PHYTOPLANKTON}

Tiny, microscopic marine algae (also known as microalgae) that require sunlight in order to grow.

Figure 1

Eutrophication at a waste water outlet in the Potomac River, Washington, D.C. The water in this river, is bright green because it has undergone eutrophication, due to excess nitrogen and other nutrients polluting the water, which has led to increased phytoplankton and algal blooms, so the water has become cloudy and can turn different colors, such as green, yellow, red, or brown, depending on the algal blooms (Wikimedia Commons: https:// commons.wikimedia. org/wiki/Category: Eutrophication\#/ media/File:Potomac green_water.JPG). called eutrophication. Eutrophication happens when too much nitrogen enriches the water, causing excessive growth of plants and algae. Too much nitrogen can even cause a lake to turn bright green or other colors, with a "bloom" of smelly algae called phytoplankton (see Figure 1)! When the phytoplankton dies, microbes in the water decompose them. The process of decomposition reduces the amount of dissolved oxygen in the water, and can lead to a "dead zone" that does not have enough oxygen to support most life forms. Organisms in the dead zone die from lack of oxygen. These dead zones can happen in freshwater lakes and also in coastal environments where rivers full of nutrients from agricultural runoff (fertilizer overflow) flow into oceans [4].

Figure 2 shows the stages of Eutrophication (open access Wikimedia Commons image from https://commons.m.wikimedia.org/wiki/ File:Eutrophicationmodel.svg).

Can eutrophication be prevented? Yes! People who manage water resources can use different strategies to reduce the harmful effects of algal blooms and eutrophication of water surfaces. They can re-reroute excess nutrients away from lakes and vulnerable costal zones, use herbicides (chemicals used to kill unwanted plant growth) or algaecides (chemicals used to kill algae) to stop the algal blooms, and reduce the quantities or combinations of nutrients used in agricultural fertilizers, among other techniques [5]. But, it can often be hard to find the origin of the excess nitrogen and other nutrients.

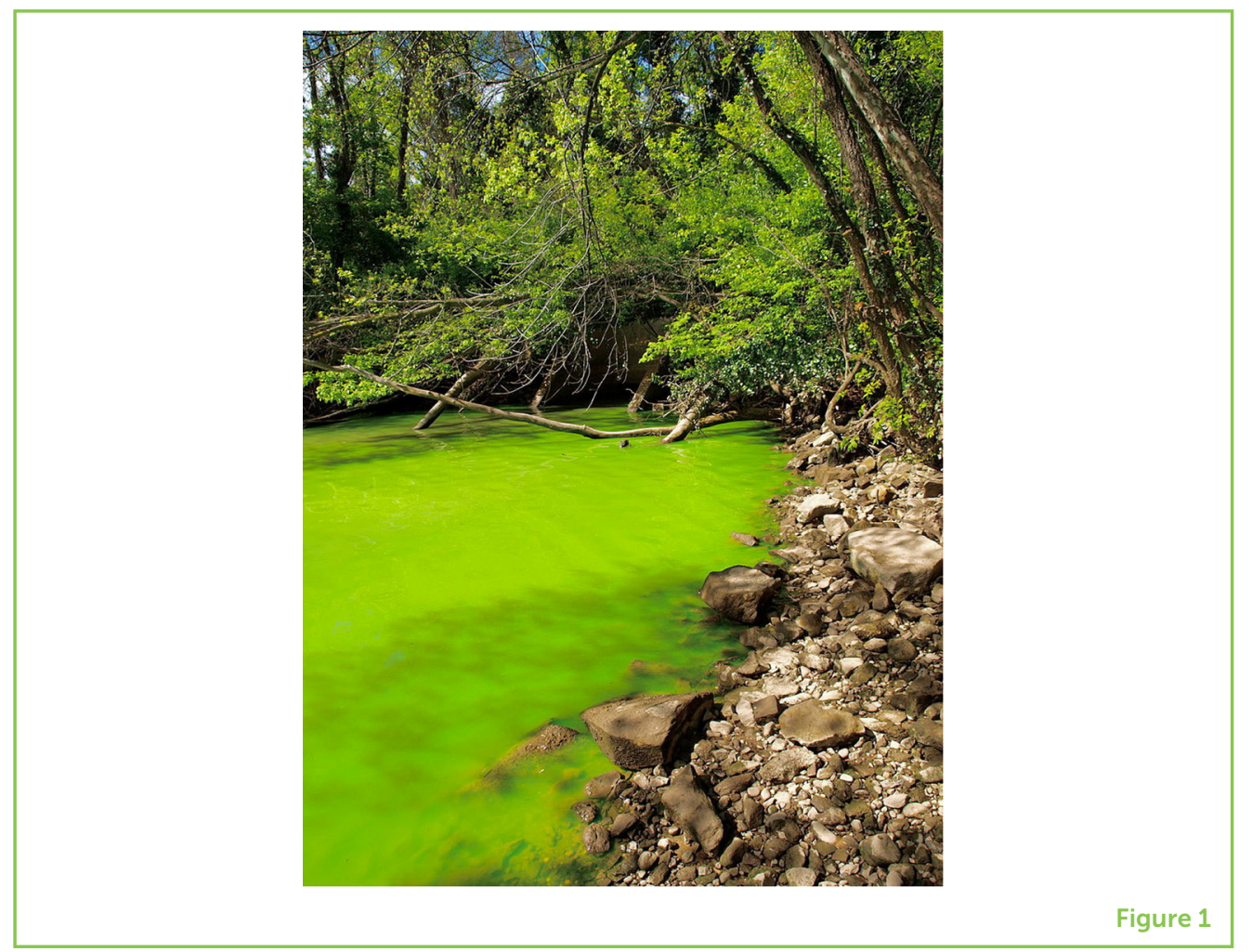




\section{Figure 2}

Stages of eutrophication (1) Excess nutrients end up in the soil and ground. (2) Some nutrients become dissolved in water and leach or leak into deeper soil layers. Eventually, they get drained into a water body, such as a lake or pond. (3) Some nutrients run off from over the soils and ground directly into the water. (4) The extra nutrients cause algae to bloom. (5) Sunlight becomes blocked by the algae. (6) Photosynthesis and growth of plants under the water will be weakened or potentially stopped. (7) Next, the algae bloom dies and falls to the bottom of the water body. Then, bacteria begin to decompose or break up the remains, and use up oxygen in the process.

(8) The decomposition process causes the water to have reduced oxygen, leading to "dead zones." Bigger life forms like fish cannot breathe and die. The water body has now undergone eutrophication.

\section{BIOREMEDIATION}

\section{Using other}

microorganisms or tiny living creatures to eat and break down pollution in order to clean a polluted site.

\section{BACTERIA}

Microscopic living organisms that usually contain only one cell and are found everywhere. Bacteria can cause decomposition or breaking down, of organic material in soils.

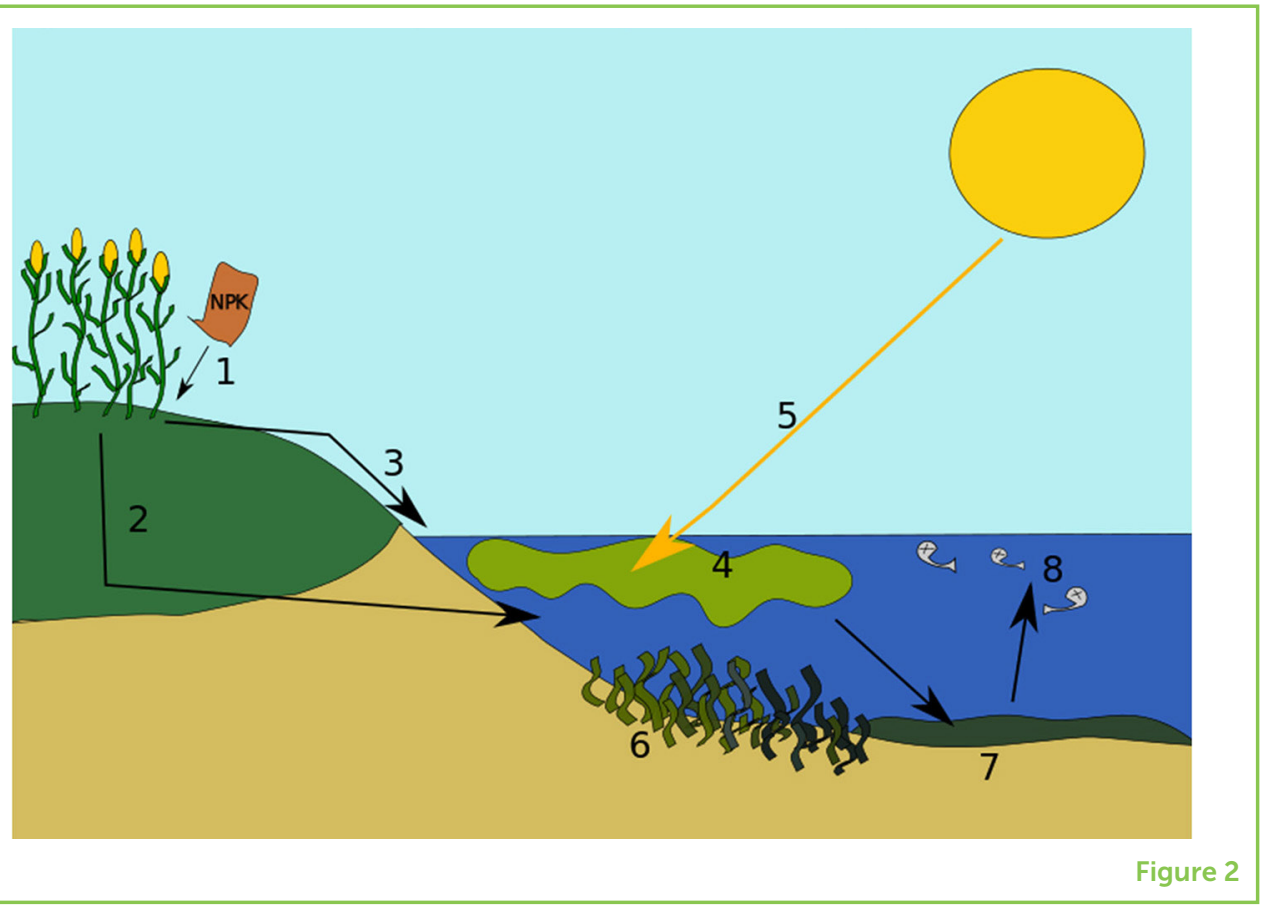

Once a lake has undergone eutrophication, it is even harder to do damage control. Algaecides can be expensive, and they also do not correct the source of the problem: the excess nitrogen or other nutrients that caused the algae bloom in the first place! Another potential solution is called bioremediation, which is the process of purposefully changing the food web in an aquatic ecosystem to reduce or control the amount of phytoplankton. For example, water managers can introduce organisms that eat phytoplankton, and these organisms can help reduce the amounts of phytoplankton, by eating them!

\section{WHAT EXACTLY IS THE NITROGEN CYCLE?}

The nitrogen cycle is a repeating cycle of processes during which nitrogen moves through both living and non-living things: the atmosphere, soil, water, plants, animals and bacteria. In order to move through the different parts of the cycle, nitrogen must change forms. In the atmosphere, nitrogen exists as a gas $\left(\mathrm{N}_{2}\right)$, but in the soils it exists as nitrogen oxide, $\mathrm{NO}$, and nitrogen dioxide, $\mathrm{NO}_{2}$, and when used as a fertilizer, can be found in other forms, such as ammonia, $\mathrm{NH}_{3}$, which can be processed even further into a different fertilizer, ammonium nitrate, or $\mathrm{NH}_{4} \mathrm{NO}_{3}$.

There are five stages in the nitrogen cycle, and we will now discuss each of them in turn: fixation or volatilization, mineralization, nitrification, immobilization, and denitrification. In this image, microbes in the soil turn nitrogen gas $\left(\mathrm{N}_{2}\right)$ into what is called volatile ammonia $\left(\mathrm{NH}_{3}\right)$, 
Figure 3

Stages of the nitrogen cycle. The Nitrogen Cycle: Nitrogen cycling through the various forms in soil determines the amount of nitrogen available for plants to uptake. Source: https://www. agric.wa.gov.au/ soil-carbon/ immobilisation-soilnitrogen-heavystubble-loads.

\section{LEACHING}

When a mineral or chemical (such as nitrate, or $\mathrm{NO}_{3}$ ) drains away from soil or other ground material and leaks into surrounding area.

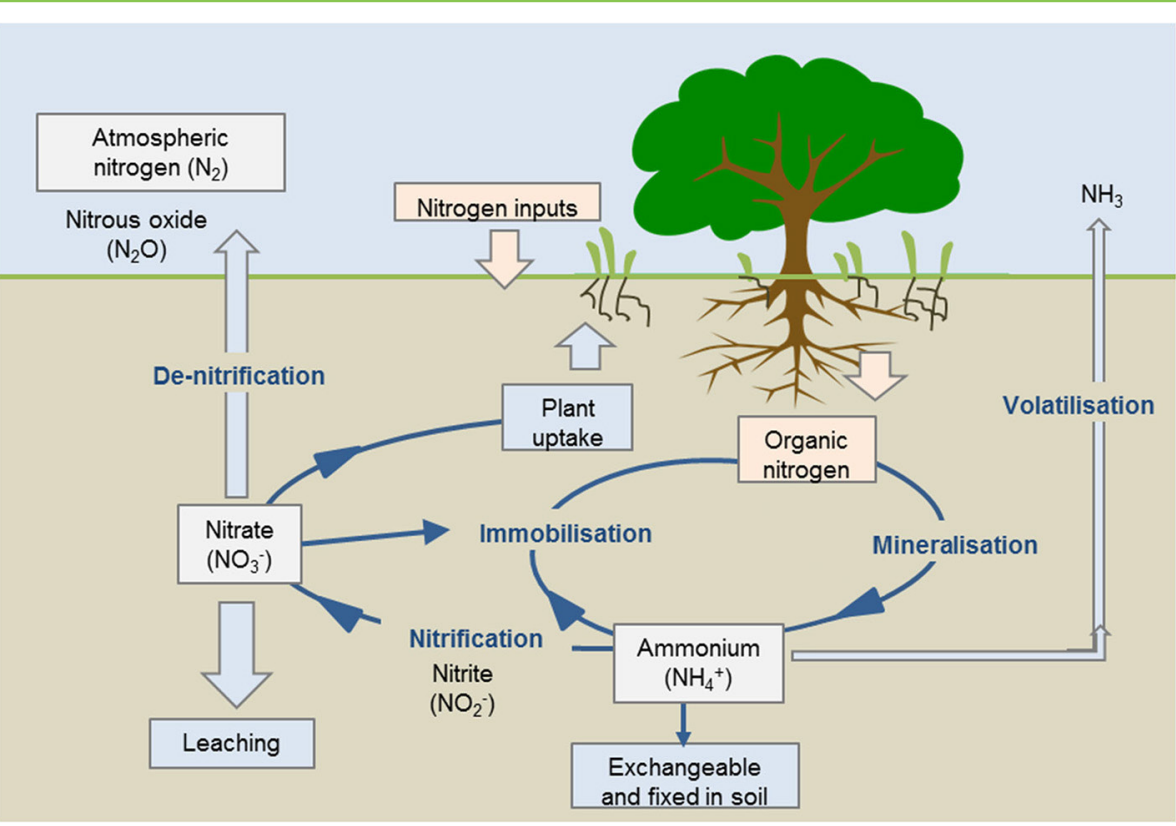

Figure 3

so the fixation process is called volatilization. Leaching is where certain forms of nitrogen (such as nitrate, or $\mathrm{NO}_{3}$ ) becomes dissolved in water and leaks out of the soil, potentially polluting waterways.

\section{STAGE 1: NITROGEN FIXATION}

In this stage, nitrogen moves from the atmosphere into the soil. Earth's atmosphere contains a huge pool of nitrogen gas $\left(\mathrm{N}_{2}\right)$. But this nitrogen is "unavailable" to plants, because the gaseous form cannot be used directly by plants without undergoing a transformation. To be used by plants, the $\mathrm{N}_{2}$ must be transformed through a process called nitrogen fixation. Fixation converts nitrogen in the atmosphere into forms that plants can absorb through their root systems.

A small amount of nitrogen can be fixed when lightning provides the energy needed for $\mathrm{N}_{2}$ to react with oxygen, producing nitrogen oxide, $\mathrm{NO}$, and nitrogen dioxide, $\mathrm{NO}_{2}$. These forms of nitrogen then enter soils through rain or snow. Nitrogen can also be fixed through the industrial process that creates fertilizer. This form of fixing occurs under high heat and pressure, during which atmospheric nitrogen and hydrogen are combined to form ammonia $\left(\mathrm{NH}_{3}\right)$, which may then be processed further, to produce ammonium nitrate $\left(\mathrm{NH}_{4} \mathrm{NO}_{3}\right)$, a form of nitrogen that can be added to soils and used by plants.

Most nitrogen fixation occurs naturally, in the soil, by bacteria. In Figure 3 (above), you can see nitrogen fixation and exchange of form occurring in the soil. Some bacteria attach to plant roots and have a symbiotic 


\section{LEGUMES}

A member of the pea family: beans, lentils, soybeans, peanuts and peas, are plants with seed pods that split in half. (beneficial for both the plant and the bacteria) relationship with the plant [6]. The bacteria get energy through photosynthesis and, in return, they fix nitrogen into a form the plant needs. The fixed nitrogen is then carried to other parts of the plant and is used to form plant tissues, so the plant can grow. Other bacteria live freely in soils or water and can fix nitrogen without this symbiotic relationship. These bacteria can also create forms of nitrogen that can be used by organisms.

\section{STAGE 2: MINERALIZATION}

This stage takes place in the soil. Nitrogen moves from organic materials, such as manure or plant materials to an inorganic form of nitrogen that plants can use. Eventually, the plant's nutrients are used up and the plant dies and decomposes. This becomes important in the second stage of the nitrogen cycle. Mineralization happens when microbes act on organic material, such as animal manure or decomposing plant or animal material and begin to convert it to a form of nitrogen that can be used by plants. All plants under cultivation, except legumes (plants with seed pods that split in half, such as lentils, beans, peas or peanuts) get the nitrogen they require through the soil. Legumes get nitrogen through fixation that occurs in their root nodules, as described above.

The first form of nitrogen produced by the process of mineralization is ammonia, $\mathrm{NH}_{3}$. The $\mathrm{NH}_{3}$ in the soil then reacts with water to form ammonium, $\mathrm{NH}_{4}$. This ammonium is held in the soils and is available for use by plants that do not get nitrogen through the symbiotic nitrogen fixing relationship described above.

\section{STAGE 3: NITRIFICATION}

The third stage, nitrification, also occurs in soils. During nitrification the ammonia in the soils, produced during mineralization, is converted into compounds called nitrites, $\mathrm{NO}_{2}^{-}$, and nitrates, $\mathrm{NO}_{3}^{-}$. Nitrates can be used by plants and animals that consume the plants. Some bacteria in the soil can turn ammonia into nitrites. Although nitrite is not usable by plants and animals directly, other bacteria can change nitrites into nitrates - a form that is usable by plants and animals. This reaction provides energy for the bacteria engaged in this process. The bacteria that we are talking about are called nitrosomonas and nitrobacter. Nitrobacter turns nitrites into nitrates; nitrosomonas transform ammonia to nitrites. Both kinds of bacteria can act only in the presence of oxygen, $\mathrm{O}_{2}$ [7]. The process of nitrification is important to plants, as it produces an extra stash of available nitrogen that can be absorbed by the plants through their root systems. 
MICROORGANISM

An organism, or living thing, that is too tiny to be seen without a microscope, such as a bacterium.

\section{STAGE 4: IMMOBILIZATION}

The fourth stage of the nitrogen cycle is immobilization, sometimes described as the reverse of mineralization. These two processes together control the amount of nitrogen in soils. Just like plants, microorganisms living in the soil require nitrogen as an energy source. These soil microorganisms pull nitrogen from the soil when the residues of decomposing plants do not contain enough nitrogen. When microorganisms take in ammonium $\left(\mathrm{NH}_{4}{ }^{+}\right)$and nitrate $\left(\mathrm{NO}_{3}{ }^{-}\right)$, these forms of nitrogen are no longer available to the plants and may cause nitrogen deficiency, or a lack of nitrogen. Immobilization, therefore, ties up nitrogen in microorganisms. However, immobilization is important because it helps control and balance the amount of nitrogen in the soils by tying it up, or immobilizing the nitrogen, in microorganisms.

\section{STAGE 5: DENITRIFICATION}

In the fifth stage of the nitrogen cycle, nitrogen returns to the air as nitrates are converted to atmospheric nitrogen $\left(\mathrm{N}_{2}\right)$ by bacteria through the process we call denitrification. This results in an overall loss of nitrogen from soils, as the gaseous form of nitrogen moves into the atmosphere, back where we began our story.

\section{NITROGEN IS CRUCIAL FOR LIFE}

The cycling of nitrogen through the ecosystem is crucial for maintaining productive and healthy ecosystems with neither too much nor too little nitrogen. Plant production and biomass (living material) are limited by the availability of nitrogen. Understanding how the plant-soil nitrogen cycle works can help us make better decisions about what crops to grow and where to grow them, so we have an adequate supply of food. Knowledge of the nitrogen cycle can also help us reduce pollution caused by adding too much fertilizer to soils. Certain plants can uptake more nitrogen or other nutrients, such as phosphorous, another fertilizer, and can even be used as a "buffer," or filter, to prevent excessive fertilizer from entering waterways. For example, a study done by Haycock and Pinay [8] showed that poplar trees (Populus italica) used as a buffer held on to $99 \%$ of the nitrate entering the underground water flow during winter, while a riverbank zone covered with a specific grass (Lolium perenne L.) held up to $84 \%$ of the nitrate, preventing it from entering the river. 
As you have seen, not enough nitrogen in the soils leaves plants hungry, while too much of a good thing can be bad: excess nitrogen can poison plants and even livestock! Pollution of our water sources by surplus nitrogen and other nutrients is a huge problem, as marine life is being suffocated from decomposition of dead algae blooms. Farmers and communities need to work to improve the uptake of added nutrients by crops and treat animal manure waste properly. We also need to protect the natural plant buffer zones that can take up nitrogen runoff before it reaches water bodies. But, our current patterns of clearing trees to build roads and other construction worsen this problem, because there are fewer plants left to uptake excess nutrients. We need to do further research to determine which plant species are best to grow in coastal areas to take up excess nitrogen. We also need to find other ways to fix or avoid the problem of excess nitrogen spilling over into aquatic ecosystems. By working toward a more complete understanding of the nitrogen cycle and other cycles at play in Earth's interconnected natural systems, we can better understand how to better protect Earth's precious natural resources.

\section{REFERENCES}

1. Britto, D. T., and Kronzuker, H. J. 2002. $\mathrm{NH}_{4}{ }^{+}$toxicity in higher plants: a critical review. J. Plant Physiol. 159:567-84. doi: 10.1078/0176-1617-0774

2. Weathers, K. C., Groffman, P. M., Dolah, E. V., Bernhardt, E., Grimm, N. B., McMahon, K., et al. 2016. Frontiers in ecosystem ecology from a community perspective: the future is boundless and bright. Ecosystems 19:753-70. doi: 10.1007/s10021-016-9967-0

3. Brady, N., and Weil, R. 2010. "Nutrient cycles and soil fertility," in Elements of the Nature and Properties of Soils, 3rd Edn, ed V. R. Anthony (Upper Saddle River, NJ: Pearson Education Inc.), 396-420.

4. Foth, H. 1990. Chapter 12: "Plant-Soil Macronutrient Relations," in Fundamentals of Soil Science, 8th Edn, ed John Wiley and Sons (New York, NY: John Wiley Company), 186-209.

5. Chislock, M. F., Doster, E., Zitomer, R. A., and Wilson, A. E. 2013. Eutrophication: causes, consequences, and controls in aquatic ecosystems. Nat. Educ. Knowl. 4:10. Available online at: https://www.nature.com/scitable/knowledge/library/ eutrophication-causes-consequences-and-controls-in-aquatic-102364466

6. Peoples, M. B., Herridge, D. F., and Ladha, J. K. 1995. Biological nitrogen fixation: an efficient source of nitrogen for sustainable agricultural production? Plant Soil 174:3-28. doi: 10.1007/BF00032239

7. Manahan, S. E. 2010. Environmental Chemistry, 9th Edn. Boca Raton, FL: CRC Press, 166-72.

8. Haycock, N. E., and Pinay, G. 1993. Groundwater nitrate dynamics in grass and poplar vegetated riparian buffer strips during the winter. J. Environ. Qual. 22:273-8. doi: 10.2134/jeq1993.00472425002200020007x 
SUBMITTED: 17 April 2018; ACCEPTED: 18 February 2019;

PUBLISHED ONLINE: 12 March 2019.

EDITED BY: Mark A. Brandon, The Open University, United Kingdom

CITATION: Aczel MR (2019) What is the Nitrogen Cycle and Why Is It Key to Life? Front. Young Minds 7:41. doi: 10.3389/frym.2019.00041

CONFLICT OF INTEREST STATEMENT: The author declares that the research was conducted in the absence of any commercial or financial relationships that could be construed as a potential conflict of interest.

COPYRIGHT @ 2019 Aczel. This is an open-access article distributed under the terms of the Creative Commons Attribution License (CC BY). The use, distribution or reproduction in other forums is permitted, provided the original author(s) and the copyright owner(s) are credited and that the original publication in this journal is cited, in accordance with accepted academic practice. No use, distribution or reproduction is permitted which does not comply with these terms.

\section{YOUNG REVIEWERS}

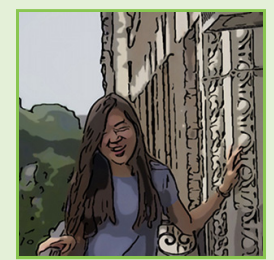

\section{JULIETTE, AGE: 14}

My name is Juliette and I am a rising freshman. I learned how to play chess at an early age and I have been playing and competing since then. I also love to play tennis. In addition to English, I speak Spanish and Mandarin. At home, I have a hamster named Pumbaa, in reference to the warthog in Lion King.

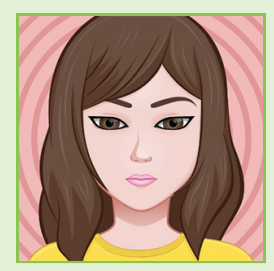

\section{CLAIRE, AGE: 15}

I go to high school in New York, where I spend my time writing poetry and playing the piano.

\section{AUTHOR}

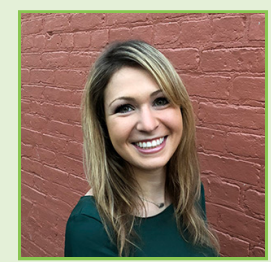

\section{MIRIAM R. ACZEL}

I am a President's Ph.D. Scholar at Imperial College London. My research looks at how drilling for shale gas (natural gas trapped inside shale rock) affects both human health and the environment. I am also the co-Founder and co-Director of the Amir D. Aczel Foundation for Research and Education in Science and Mathematics, which works to encourage young students in Cambodia to study science and math. I was born on Earth Day, so naturally I love being outside and look for any excuse to spend time with animals of all shapes and sizes! *miriam.aczel14@imperial.ac.uk 